\title{
INTEGRAL INDICATORS BASED ON COMPETITIVENESS CAPACITY CHARACTERISTICS OF REGIONAL REAL ESTATE MARKETS OF UKRAINE
}

\section{- Kostiantyn Pavlov, Olena Pavlova, Volodymyr Kupchak}

\begin{abstract}
This article summarises the methodological approaches, principles, methods, and tools of scientific knowledge inherent in a single complex research model of regional residential real estate markets competitiveness (RREM). The development and implementation of the proposed model can provide a deep regional analysis of component imbalances, and the implementation of the methodological steps can foster the comparative and targeted analysis of Ukrainian regions. The methodological tools of this complex study of the country's RREM as well as the strategic and tactical measures for its further regulation have been developed based on a comprehensive review of methodological principles and approaches. The basis of this study takes onto account general scientific and special knowledge of economic phenomena and processes. The scientific background developed was both empirical and theoretical. At the empirical level, observation, measurement, experiment and modelling were employed, while equal importance was placed on the special methodological principles involved. Achievement of the research goals required the use of such methods as: balance and index, decomposition, aggregation, analogous, logical, classification, ranking and extrapolation, expert evaluations and systematization along with a direct survey. In order to determine the level of regional housing market competitiveness, the implementation of future analytical assessments was carried out with regard to the following integrated factors: housing demand, housing supply, housing affordability, purchasing capacity of citizens, the region's comfort level, as well as certain geographical and cultural features of the region.
\end{abstract}

Keywords: competition, competitiveness, housing market, housing, residential property, real estate in Ukraine, integral indicator

JEL Classification: D40, D41, D43, F12, L13, L40, L41, L85, R21, R31

Received: May, 2019

1st Revision: June, 2019

Accepted: August, 2019 


\section{INTRODUCTION}

From a general perspective, the Ukrainian economy is made up of naturally different but related markets, forming a rather complicated structure. The level of development and the functional characteristics of individual segments of this structure, including the real estate market, are unique at both state and regional levels. Meanwhile, taking into account the constantly increasing level of demand for real estate, the low level of solvency of citizens, as well as a significant imbalance in the development of certain regional real estate markets segments, it is clear that competitive relationships among market entities as well as the mechanism of their functional characteristics are very relevant (Garbar, 2019; Mann \& Wright, 2010).

The real estate market is regarded as a component of a national economy, since it contains a lion's share of national wealth. Market stability is considered to be one of the most difficult processes of market transformations within a state. The functional intensity of real estate markets is a prerequisite for the sustainable development of cities and regions, as the regional management processes involved serve as the basis for increasing the efficiency level of all processes implemented within the systems of national government and local self-government (Keynes, 1999; Samuelson \& William, 2010).

In the conditions of transformational processes occurring in Ukraine, real estate markets are marked by institutional asymmetry and structural incompleteness, and the critical economic situation that has arisen due to lower efficiency indicators of the economy, the imperfection of the financial and credit system, the general decline in production, the decline in real income, and the population's deepening social stratification naturally stifle market development (Fatkhutdinov, 2002; Filipenko, 2010).

The formation process of regional residential real estate markets flows consecutively under the influence of various factors such as demographic, economic, social and climatic issues. In turn, the process of setting real estate market value depends not only on the existing market conditions (supply and demand), but also on other functional features such as: risks involved in capital investment; potential income level; the probable price level of a real estate object on sale as of a certain date, etc. (Mann, 2007; Zotov, 2008).

\section{THEORETICAL BACKGROUND}

Scientific approaches to competitiveness have already been outlined by many researchers, all of whom have studied the indispensable prerequisites of objects, e.g. production, industry, region as a production factor, in terms of their competitive benefits. However, we maintain that the competitive advantages stemming from production factors do not reflect in any way the potential of the object. Provided that a researched region maintains a high level of scientific and innovative potential, this can be classified as an advantage. However, if the position of competitors is stronger, this presupposes that the existing benefits of a weaker region can induce the development and accumulation of its potential. Consequently, we can conclude that the competitive advantage is inherently comparative and rational, which can result in the effective planning of the future use of production factors. 
Bazylyuk (2002) and Porter (2005) have treated competitiveness as a macroeconomic phenomenon, one determined by the efficiency of the use of the resources involved. Porter (2005) indicates that the core well-being of a region is dependent on the productivity of the economy, which conversely affects the competitiveness of regional residential real estate markets. The basis for a region's competitiveness as a research was the way forward by many scientists (Pozniak, 2015).

As indicated in the works of $\mathrm{K}$. Marx, industrial competition is considered to be necessary for market prices stabilization as well as the various individual values of goods within one production sphere of (Marx, 1867). We believe that competitive autonomy should be understood as the ability of goods, services and industries to form a system of accumulated technical, economic, and organizational forces (Ginevicius, 2019). The real estate competitiveness represents a set of characteristics distinguishing real estate from similar objects by the degree of a single consumer's satisfaction, the purchase cost and further exploitation, as well as its ability to be selected by the consumer from other groups of similar objects on sale, due to considerably higher economic and technical characteristics as well as technical and economic parameters (Mann, 2007; Pavlov, 2016).

On the one hand, competition in regional housing markets is ostensibly a very important prerequisite for market functioning and further development, as it contributes to the continuous implementation of the most effective methods of production by market participants, to offer new concepts and price proposals as well as the opening up of new segments (Piotrowska, 2019). On the other hand, forms of competition are primarily bound to the state of regional markets, i.e. their character and tendencies (Mann, 2007; Valitov, 2006).

\section{RESEARCH OBJECTIVE, METHODOLOGY AND DATA}

This competitiveness level determination of regional residential real estate markets in Ukraine used a set of statistical indicators and integral components such as demand, supply, level of comfort, cultural and geographical advantages, housing affordability, purchasing capacity of citizens, etc. for the period of 2007-2016.

The indicated regional indicators will create conditions for a diagnostics study of the value of individual influence factors in the formation of a high competitiveness index and to determine the priority directions of value increase. The real estate market in Ukraine has experienced some recovery recently prompted by the capital influx from bank withdrawals during Ukraine's "bankruptcy" in 2016-2017. On the other hand, the purchasing power of Ukrainians remains low and this has led to falling real estate prices in recent years. This is a current trend with a number of regional peculiarities (Strishenets, 2018).

As already mentioned, regional housing market competitiveness depends on a number of factors such as housing demand, housing supply, housing prices, the purchasing capacity of citizens, along with cultural and geographical features of the region. These factors constitute an integral group expression of other factors such as income of citizens, average salary, number of structures built, and living conditions in the region. Carrying out future analytical assessments, we will assume that the competitiveness of the regional housing market is determined by the following integral factors: housing demand (housing), housing supply (HS), housing affordability (A), 
purchasing capacity of citizens (PCC), level of comfort of the region (CL), as well as geographical and cultural advantages of the region (GCA) (Pavlov, 2018).

To assess the level of regional housing market competitiveness in the region, a complex of statistical indicators of its social and economic development should be used. The set of indicators can be represented as matrix $\mathrm{X}$ :

$X=\left[\begin{array}{llllll}x_{11} & x_{12} & \mathrm{~K} & x_{1 j} & \mathrm{~K} & x_{1 m} \\ x_{21} & x_{22} & \mathrm{~K} & x_{2 j} & \mathrm{~K} & x_{2 m} \\ \mathrm{~K} & \mathrm{~K} & \mathrm{~K} & \mathrm{~K} & \mathrm{~K} & \mathrm{~K} \\ x_{i 1} & x_{i 2} & \mathrm{~K} & x_{i j} & \mathrm{~K} & x_{i m} \\ \mathrm{~K} & \mathrm{~K} & \mathrm{~K} & \mathrm{~K} & \mathrm{~K} & \mathrm{~K} \\ x_{n 1} & x_{n 2} & \mathrm{~K} & x_{n j} & \mathrm{~K} & x_{n m}\end{array}\right]$,

where $\mathrm{n}$ is the number of regions, $\mathrm{m}$ is the number of indicators, and xij is the $\mathrm{j}$-th indicator for i-th region. In order to evaluate the competitiveness of individual regional real estate markets, it is necessary to formulate a comprehensive assessment based on many indicators. To obtain such a comprehensive assessment, we have used the taxonomic development level method (Plyuta, 1980). The advantages of this method are that it enables us to obtain a stratum-specific quantitative assessment of the state of a region in the form of an integral indicator combining the features of all other indicators. The integral indicator ranges from 0 to $\mathrm{II}_{\max }$, where $\mathrm{II}_{\max }$ is a small positive number. Thus, the obtained figures are easily subjected to ranking and economic interpretation. In our case, the region's development level will reflect the competitiveness and investment attractiveness level of the region in terms of housing and development. Therefore, for the given indicator, the term "region's competitiveness level" will be used throughout the communication of our results below. We have constructed an algorithm for determining the calculation of the competitiveness level of RREM in accordance with the method, but in a slightly modified form. Our algorithm looks as given below. At the first stage, the matrix of input indicators is formed:

$X=\left(x_{i j}\right), i=1, n ; j=1, m$,

with $-x_{i j}$ the value of the $j$-indicator for $-i$ region of Ukraine (or Kiev).

At the second stage of the algorithm's step, the standardisation procedure is resorted to for the initial indicators, since they can be specified in different units of measurement. To do this, initially, there is a division of indicators into stimulants and destimulants. In fact, indicators that have a positive impact on the housing market competitiveness will be considered as stimulants, and other indicators as destimulants. Thus, for high residential real estate market competitiveness in the region, high values of stimulant indicators and low values of destimulants are required.

For each indicator $x$, we determine the average selective value $\bar{x}$ and the standard deviation. The standardisation of the stimulator indicator yields its dimensionless form by the rule:

$Z=\frac{x-\bar{x}}{S_{x}}$

Standardisation of the destimulator indicator occurs according to another rule:

$Z=\frac{\bar{x}-x}{S_{x}}$. 
The use of a standardised indicator is convenient because of its dimensionlessness, and most of its values range from -2 to +2 . The use of standardised indicators makes it easy to rank regions according to different indicators. All standardised indicators should be evaluated as follows: a high value (approximate to +2 ) is evidence of a high level of quality, a low value (approximate to -2) is a low-quality level reflection.

At the third stage, with standardised indicators as the basis, a "negative standard" is constructed, that is, the vector with the following coordinates

$$
P_{0}=\left(z_{01}, z_{02}, K, z_{0 n}\right) \text {, where } z_{0 s}=\min _{\mathrm{r}} z_{s,}, r=1, n
$$

The distance from the current indicator to the negative standard can serve as an indicator of this object's positive development (the greater the distance - the better the state of the object). The "distance to standard" indicator can be used to rank RREM by different indicators, that is, to build RREM ratings.

Rating assessments can be calculated not only for individual statistical indicators, but also for the integral components of the RREM competitiveness such as: demand, supply, comfort level, cultural and geographical advantages, housing affordability (price), purchasing capacity of citizens, etc. Such local rating assessments enable to determine the competitiveness level of the region in terms of housing and development, analyse the role of individual factors in the formation of a high competitiveness index and determine the priority directions of its increase.

In accordance with the above-mentioned points, we will therefore form the following hierarchical structure of subsets of the competitiveness indicators set:

- Housing demand (DE): the number of flats purchased per time unit (1 year) - (FN); number of the region's citizens $(\mathrm{CN})$.

- Housing supply (SU): capital investment in housing construction, in UAH million (CI); the number of built flats per 1 year $(\mathrm{BFN})$; residential area let into operation per 1 year, in sq. $\mathrm{m}$. per 1,000 people (HA); growth rate of the given residential area, in per cent (GR).

- Affordability (price) of housing, in US \$ / in sq. m. (A)

- Purchasing capacity of citizens (PCC): GRP per person, thousand UAH / person (GRP); average salary, UAH (AS); income per capita, in UAH (CI); unemployment rate, in \% (UR).

- Region's comfort level (CL): average area of the housing stock for 1 person, in sq. m. (HS); average life expectancy, in years (LE); amount of harmful emissions into the atmosphere, thousand tons (EA); criminal offenses number per 10,000 people (CO).

- Region's geographical and cultural advantages (GCA): geographical features (proximity to the combat zone, the EU border proximity, in points (GA); presence of cultural and historical monuments, tourist attractions, in points (CA).

This system of indicators generates a statistical ratings system, both according to the whole set of indicators, and to their individual groups, which allows to form different types of ratings in RREM. An integral indicator (II) of the estimation of $i$-th area's state in a certain direction can be obtained by using a set $k \leq m$ of standardised dimensionless indicators of the given area 
$\left\langle Z_{i}\right\rangle=\left(z_{i 1}, z_{i 2}, \mathrm{~K}, z_{i k}\right)$ and comparing them with the indicators of the "negative standard" $\left\langle Z_{0}\right\rangle=\left(z_{01}, z_{02}, \mathrm{~K}, z_{0 k}\right)$.

$$
I I_{i}=\sqrt{\left[\left(z_{i 1}-z_{01}\right)^{2}+\left(z_{i 2}-z_{02}\right)^{2}+\mathrm{K}+\left(z_{i k}-z_{0 k}\right)^{2}\right] / k}
$$

We suggested dividing the regions of Ukraine into six RREMs (regional residential real estate markets), each consisting of several neighboring regions, with similar construction market indicators and housing market indicators. The integral indicator calculation of a region's status assessment including several areas is carried out in two stages. At the first stage, an integral indicator of the region is formed for each $j$-th statistical data indicator (GRP per person, income per person, etc.). For this purpose, the following relations are used:

- for western RREM: $\quad I_{j, w}=\sqrt{\left(z_{2 j}-z_{0 j}\right)^{2}+\left(z_{6 j}-z_{0 j}\right)^{2}+\left(z_{8 j}-z_{0 j}\right)^{2}+\left(z_{12 j}-z_{0 j}\right)^{2}+}$

$$
\longdiv { + ( z _ { 1 6 j } - z _ { 0 j } ) ^ { 2 } + ( z _ { 1 8 j } - z _ { 0 j } ) ^ { 2 } + ( z _ { 2 1 j } - z _ { 0 j } ) ^ { 2 } + ( z _ { 2 3 j } - z _ { 0 j } ) ^ { 2 } ] / 8 }
$$

- for central RREM: $I_{j, c e n t}=\sqrt{\left.\left(z_{1 j}-z_{0 j}\right)^{2}+\left(z_{5 j}-z_{0 j}\right)^{2}+\left(z_{9 j}-z_{0 j}\right)^{2}+\left(z_{10 j}-z_{0 j}\right)^{2}+\left(z_{22 j}-z_{0 j}\right)^{2}\right] / 5}$

- for northern RREM: $\quad I I_{j, n}=\sqrt{\left[\left(z_{15 j}-z_{0 j}\right)^{2}+\left(z_{17 j}-z_{0 j}\right)^{2}+\left(z_{19 j}-z_{0 j}\right)^{2}+\left(z_{24 j}-z_{0 j}\right)^{2}\right] / 4}$

- for southern RREM: $\quad I_{j, s}=\sqrt{\left[\left(z_{13 j}-z_{0 j}\right)^{2}+\left(z_{14 j}-z_{0 j}\right)^{2}+\left(z_{20 j}-z_{0 j}\right)^{2}\right] / 3}$

- for eastern RREM: $\quad I I_{j, e}=\sqrt{\left[\left(z_{3 j}-z_{0 j}\right)^{2}+\left(z_{4 j}-z_{0 j}\right)^{2}+\left(z_{7 j}-z_{0 j}\right)^{2}+\left(z_{11 j}-z_{0 j}\right)^{2}\right] / 4}$

- for capital RREM:

$$
I I_{j, \text { cap }}=z_{25 j}-z_{0 j}
$$

When constructing the calculation formulas (6) - (11), the numbers of Ukraine regions are used in the generally accepted alphabetical classification: Vinnytska -1, Volynska 2, ..., Chernihivska - 24, Kyiv - 25. At the second stage, the integral indicator of the selected region's state in the chosen direction can be obtained using the ratio (5).

\section{RESULTS AND DISCUSSION}

\section{Analysis of the integral component "housing demand"}

It is necessary to illustrate the algorithm described above by integral indicator calculations of "housing demand" (Table 1). Input indicators are the number of flats purchased per 1 year (FN) and the number of inhabitants of the region $(\mathrm{CN})$. The number of flats bought was estimated by the following indicators: the mortgage agreements number (MAN) and the built flats number (BFN). The first indicator illustrates the buyer's activity in the secondary housing market, the second indicator - that of the primary market. The number of flats purchased is estimated by the ratio

$F N=M A N+0.9 B F N$.

Ratio (12) assumes that during one year, 90 per cent of newly built flats are purchased. The housing demand can be determined by the ratio of the number of dwellings purchased per time unit (1 year) to the number of residents in the region. The indicator of housing demand is determined by the ratio:

$D E=F N / P N$ 
in which $\mathrm{CN}$ designates the number of the region's citizens. For an easier calculation, we will perform the normalisation of indicator ratio:

$I_{d e}=\left(D E-D E_{\text {min }}\right) /\left(D E_{\text {max }}-D E_{\text {min }}\right)$,

in which $\mathrm{DE}_{\min }$ is the minimum indicator value within all regions, $\mathrm{DE}_{\max }$ is the maximum value of this indicator. The calculated Ide demand index (penultimate column of Table 1) is convenient because its minimum value is 0 , the maximum value is equal to 1 , and thus it has a transparent economic interpretation: 0 - the minimum demand level, 1 - the maximum demand level. Using the housing demand index makes it easy to rank the regions by this indicator (the last column of Table 1).

As shown in the table, the highest housing demand is observed in Kyiv, Kyivska, Kharkivska and Odeska region. The lowest housing demand is in Donetska, Luganska and Zakarpatska regions.

Using Table 1, the housing demand index for Ukraine regions was calculated. For example, for the western region, the calculation of demand index (DI)is as follows:

$$
\begin{aligned}
& D I_{j, w}=\sqrt{\left[(0.220-0.0)^{2}+(0.123-0.0)^{2}+(0.185-0.0)^{2}+(0.342-0.0)^{2}+\right.} \\
& \sqrt{\left.+(0.240-0.0)^{2}+(0.207-0.0)^{2}+(0.314-0.0)^{2}+(0.221-0.0)^{2}\right] / 8}=0.241
\end{aligned}
$$

Similarly, it is possible to calculate the housing demand index for other regions of Ukraine. The results of the calculation are provided in Table 1, 9. The highest housing demand is observed in the capital area and, and to some extent in the central RREM (due to the indicators of the Kiev region).

Tab. 1 - Housing demand of Ukraine regions according to their division into RREM, on January 1, 2017 (excluding the temporarily occupied territory of the Autonomous Republic of Crimea, the city of Sevastopol and parts of the area of anti-terrorist operation in Donetsk, Luhanska region). Source: State Statistics Service of Ukraine (2019), Ministry of Justice of

\begin{tabular}{|c|c|c|c|c|c|c|c|c|}
\hline \multicolumn{2}{|c|}{ Region } & 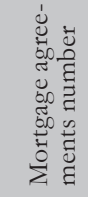 & 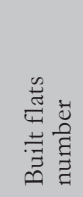 & 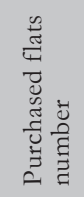 & 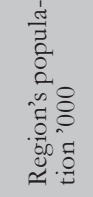 & 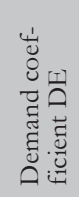 & 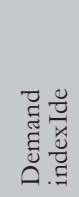 & 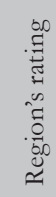 \\
\hline \multicolumn{9}{|c|}{ Western RREM } \\
\hline 1 & Volynska & 6303 & 3244 & 9223 & 1042.7 & 8.84 & 0.220 & 19 \\
\hline 2 & Rivnenska & 8179 & 3039 & 10914 & 1161.8 & 9.39 & 0.240 & 16 \\
\hline 3 & Lvivska & 22783 & 8943 & 30832 & 2534.2 & 12.17 & 0.342 & 6 \\
\hline 4 & Ternopilska & 6608 & 2726 & 9061 & 1065.7 & 8.50 & 0.207 & 21 \\
\hline 5 & Khmelnytska & 10472 & 4784 & 14778 & 1294.4 & 11.42 & 0.314 & 7 \\
\hline 6 & Zakarpatska & 5961 & 2075 & 7829 & 1259.2 & 6.22 & 0.123 & 23 \\
\hline 7 & Ivano-Frankivska & 8362 & 2832 & 10911 & 1382.3 & 7.89 & 0.185 & 22 \\
\hline 8 & Chernivetska & 6256 & 2035 & 8088 & 909.9 & 8.89 & 0.221 & 18 \\
\hline
\end{tabular}
Ukraine (2019) 


\begin{tabular}{|c|c|c|c|c|c|c|c|c|}
\hline \multicolumn{9}{|c|}{ Central RREM } \\
\hline 9 & Kyivska & 28713 & 26018 & 52129 & 1732.2 & 30.09 & 1.000 & 1 \\
\hline 10 & Zhytomyrska & 10776 & 1702 & 12308 & 1247.5 & 9.87 & 0.257 & 14 \\
\hline 11 & Vinnytska & 10975 & 4181 & 14738 & 1602.2 & 9.20 & 0.233 & 17 \\
\hline 12 & Cherkaska & 11341 & 1149 & 12375 & 1243.0 & 9.96 & 0.261 & 13 \\
\hline 13 & Kirovogradska & 8784 & 433 & 9174 & 973.1 & 9.43 & 0.241 & 15 \\
\hline \multicolumn{9}{|c|}{ Northern RREM } \\
\hline 14 & Chernihivska & 9651 & 1222 & 10751 & 1045.0 & 10.29 & 0.273 & 11 \\
\hline 15 & Sumska & 8505 & 1305 & 9680 & 1113.3 & 8.69 & 0.214 & 20 \\
\hline 16 & Poltavska & 13751 & 1703 & 15284 & 1438.9 & 10.62 & 0.285 & 8 \\
\hline 17 & Kharkivska & 33529 & 8183 & 40894 & 2718.6 & 15.04 & 0.447 & 3 \\
\hline \multicolumn{9}{|c|}{ Southern RREM } \\
\hline 18 & Odeska & 26587 & 9089 & 34767 & 2390.3 & 14.55 & 0.429 & 4 \\
\hline 19 & Mykolayivska & 11129 & 1087 & 12107 & 1158.2 & 10.45 & 0.279 & 9 \\
\hline 20 & Khersonska & 9954 & 896 & 10760 & 1062.4 & 10.13 & 0.267 & 12 \\
\hline 21 & AR Crimea & - & - & - & - & - & - & - \\
\hline 22 & SEVASTOPOL & - & - & - & - & - & - & - \\
\hline \multicolumn{9}{|c|}{ Eastern RREM } \\
\hline 23 & Dnipropetrovska & 39434 & 3203 & 42317 & 3254.9 & 13.00 & 0.372 & 5 \\
\hline 24 & Zaporizka & 17162 & 1086 & 18139 & 1753.6 & 10.34 & 0.275 & 10 \\
\hline 25 & Donetska & 18863 & 319 & 19150 & 4265.1 & 4.49 & 0.060 & 24 \\
\hline 26 & Luhanska & 6248 & 58 & 6300 & 2205.4 & 2.86 & 0.000 & 25 \\
\hline \multicolumn{9}{|c|}{ Capital RREM } \\
\hline 27 & KYIV & 53726 & 20265 & 71965 & 2906.6 & 24.76 & 0.804 & 2 \\
\hline
\end{tabular}

The lowest housing demand is characteristic of the western and eastern RREM. However, it should be noted here that in our calculations, the funds transferred from abroad by labor migrants are not taken into consideration, as there are no relevant statistics for regions. Involving external cash receipts statistics would modify the obtained indices.

Using the annual estimates of the number of flats sold and the value of housing prices in Ukraine regions, it is possible to estimate the housing market capacity (HMC) for the regions of Ukraine by the ratio:

$H M C=F N \cdot H P \cdot 50$.

Here FN - the number of flats purchased, HP - the housing price ( $\$$ for $1 \mathrm{~m}^{2}$ ), 50 - the average value of apartment area. This indicator reflects the turnover in the region for 1 year at the moment of making a housing purchase. The results of relevant calculations are given in Table 2. which explicates the evidence that the most powerful housing markets are those of Kyiv, Kyivska, Odeska, Kharkivska, Dnipropetrovska and Lvivska regions. In these regions, 66 per cent of the Ukrainian housing market is concentrated. According to our estimations, the total annual housing market capacity for Ukraine is $\$ 17.8$ billion. Table 2 also allows to analyse the share of the primary housing market in Ukraine regions. This indicator shows the intensity of 
building new housing and its acquisition by residents of the region. The largest share of primary market is characteristic of Kyivska region and therefore constitutes $44.9 \%$. High shares of the primary market (25\% - 30\%) are also observed in Volynska, Khmelnytska, Ternopilska, Lvivska, Rivnenska, Vinnytska regions and Kyiv. The data in Table 2 was used to explicate the share value calculations of primary market for the regions of Ukraine. The results of calculations are given in Table 9.

The highest share of primary market is observed for the central, western and capital RREM; whereas the lowest is for the eastern RREM.

Tab. 2 - The capacity of the housing market in Ukraine regions in terms of their division into RREM, on January 1, 2017, (excluding the temporarily occupied territory of the Autonomous Republic of Crimea, the city of Sevastopol and parts of the zone of the anti-terrorist operation in Donetska and Luhanska regions). Source: Ministry of Justice of Ukraine (2019).

\begin{tabular}{|c|c|c|c|c|c|c|c|c|}
\hline Reg & & 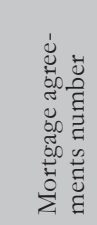 & 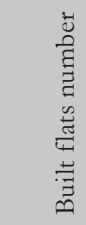 & 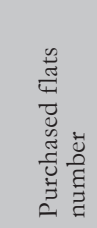 & 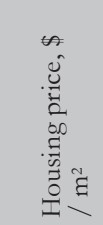 & 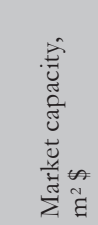 & 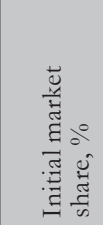 & 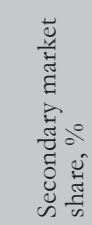 \\
\hline Wes & ern RREM & & & & & & & \\
\hline 1 & Volynska & 6303 & 3244 & 9223 & 575 & 265.1 & 31.7 & 68.3 \\
\hline 2 & Rivnenska & 8179 & 3039 & 10914 & 555 & 302.9 & 25.1 & 74.9 \\
\hline 3 & Lvivska & 22783 & 8943 & 30832 & 898 & 1384.3 & 26.1 & 73.9 \\
\hline 4 & Ternopilska & 6608 & 2726 & 9061 & 450 & 203.9 & 27.1 & 72.9 \\
\hline 5 & Khmelnytska & 10472 & 4784 & 14778 & 460 & 339.9 & 29.1 & 70.9 \\
\hline 6 & Zakarpatska & 5961 & 2075 & 7829 & 629 & 246.2 & 23.9 & 76.1 \\
\hline 7 & Ivano-Frankivska & 8362 & 2832 & 10911 & 574 & 313.1 & 23.4 & 76.6 \\
\hline 8 & Chernivetska & 6256 & 2035 & 8088 & 669 & 270.5 & 22.6 & 77.4 \\
\hline Cen & ral RREM & & & & & & & \\
\hline 9 & Kyivska & 28713 & 26018 & 52129 & 822 & 2142.5 & 44.9 & 55.1 \\
\hline 10 & Zhytomyrska & 10776 & 1702 & 12308 & 566 & 348.3 & 12.4 & 87.6 \\
\hline 11 & Vinnytska & 10975 & 4181 & 14738 & 630 & 464.2 & 25.5 & 74.5 \\
\hline 12 & Cherkaska & 11341 & 1149 & 12375 & 514 & 318.0 & 8.4 & 91.6 \\
\hline 13 & Kirovohradska & 8784 & 433 & 9174 & 473 & 217.0 & 4.2 & 95.8 \\
\hline Nor & hern RREM & & & & & & & \\
\hline 14 & Chernihivska & 9651 & 1222 & 10751 & 485 & 260.7 & 10.2 & 89.8 \\
\hline 15 & Sumska & 8505 & 1305 & 9680 & 487 & 235.7 & 12.1 & 87.9 \\
\hline 16 & Poltavska & 13751 & 1703 & 15284 & 573 & 437.9 & 10.0 & 90.0 \\
\hline 17 & Kharkivska & 33529 & 8183 & 40894 & 695 & 1421.1 & 18.0 & 82.0 \\
\hline Sout & hern RREM & & & & & & & \\
\hline 18 & Odeska & 26587 & 9089 & 34767 & 819 & 1423.7 & 23.5 & 76.5 \\
\hline
\end{tabular}




\begin{tabular}{|l|l|l|l|l|l|l|l|l|}
\hline 19 & Mykolayivska & 11129 & 1087 & 12107 & 555 & 336.0 & 8.1 & 91.9 \\
\hline 20 & Khersonska & 9954 & 896 & 10760 & 594 & 319.6 & 7.5 & 92.5 \\
\hline 21 & AR Crimea & - & - & - & - & - & - & - \\
\hline 22 & SEVASTOPOL & - & - & - & - & - & - & - \\
\hline Eastern RREM & \multicolumn{7}{|l|}{} \\
\hline 23 & Dnipropetrovska & 39434 & 3203 & 42317 & 662 & 1400.7 & 6.8 & 93.2 \\
\hline 24 & Zaporizka & 17162 & 1086 & 18139 & 599 & 543.3 & 5.4 & 94.6 \\
\hline 25 & Donetska & 18863 & 319 & 19150 & 450 & 430.9 & 1.5 & 98.5 \\
\hline 26 & Luhanska & 6248 & 58 & 6300 & 450 & 141.8 & 0.8 & 99.2 \\
\hline Capital RREM & \multicolumn{7}{|l|}{} \\
\hline 27 & KYIV & 53726 & 20265 & 71965 & 1122 & 4037.2 & 25.3 & 74.7 \\
\hline
\end{tabular}

\section{The integral component analysis of "housing supply" SU}

The housing supply is determined by such factors as the capital investment in housing construction (HC), the number of built flats per 1 year $(\mathrm{BFN})$, the residential area let into operation per 1 year (HA), the growth rate of the given residential area (GR).

All indicators shown in Table 3 are stimulants since their growth positively influences the housing supply increase. Standardisation of indicators was carried out, after which the integral housing supply SU indicator for the GR (growth rate) was calculated on the basis of the ratio:

$S U_{i}=\sqrt{\left.\left(I A_{i}-I A_{0}\right)^{2}+\left(N F B_{i}-N F B_{0}\right)^{2}+\left(H A_{i}-H A_{0}\right)^{2}+\left(G R_{i}-G R_{0}\right)^{2}\right] / 4}$

Tab. 3 - Housing supply in Ukraine regions according to their division into RREM, on January 1, 2017, (excluding the temporarily occupied territory of the Autonomous Rep. of Crimea, the city of Sevastopol and parts of the zone of anti-terrorist operation in Donetska, Luhanska regions). Source: Ministry of Justice of Ukraine (2019), State Statistics Service of Ukraine (2019)

\begin{tabular}{|c|c|c|c|c|c|c|c|c|}
\hline \multicolumn{2}{|c|}{ Region } & 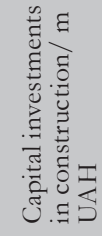 & 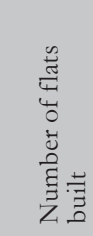 & 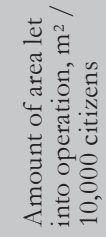 & 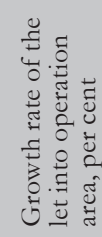 & $\begin{array}{l}\frac{1}{n} \\
\frac{1}{2} \\
0 \\
00 \\
\cdot \frac{0}{5} \\
\frac{1}{0} \\
0 \\
\frac{1}{1}\end{array}$ & 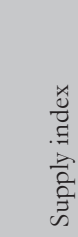 & 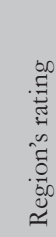 \\
\hline \multicolumn{9}{|c|}{ Western RREM } \\
\hline 1 & Volynska & 1067 & 3244 & 3504 & 118.7 & 2.58 & 0.61 & 5 \\
\hline 2 & Rivnenska & 1203 & 3039 & 2795 & 107.6 & 2.24 & 0.53 & 7 \\
\hline 3 & Lvivska & 2751 & 8943 & 3415 & 112.4 & 2.66 & 0.63 & 4 \\
\hline 4 & Ternopilska & 890 & 2726 & 2213 & 103.3 & 2.07 & 0.49 & 12 \\
\hline 5 & Khmelnytska & 3400 & 4784 & 3146 & 113.6 & 2.71 & 0.64 & 3 \\
\hline 6 & Zakarpatska & 1025 & 2075 & 2675 & 97.3 & 1.94 & 0.46 & 16 \\
\hline 7 & Ivano-Frankivska & 1813 & 2832 & 3488 & 98.2 & 2.10 & 0.50 & 11 \\
\hline 8 & Chernivetska & 686 & 2035 & 2447 & 96.6 & 1.88 & 0.45 & 18 \\
\hline
\end{tabular}




\begin{tabular}{|c|c|c|c|c|c|c|c|c|}
\hline \multicolumn{9}{|c|}{ Central RREM } \\
\hline 9 & Kyivska & 4035 & 26018 & 11922 & 110.8 & 4.22 & 1.00 & 1 \\
\hline 10 & Zhytomyrska & 505 & 1702 & 1332 & 108.5 & 2.16 & 0.51 & 8 \\
\hline 11 & Vinnytska & 949 & 4181 & 2200 & 102.3 & 2.06 & 0.49 & 13 \\
\hline 12 & Cherkaska & 482 & 1149 & 1020 & 104.9 & 2.05 & 0.49 & 14 \\
\hline 13 & Kirovohradska & 112 & 433 & 557 & 101.2 & 1.93 & 0.46 & 17 \\
\hline \multicolumn{9}{|c|}{ Northern RREM } \\
\hline 14 & Chernihivska & 205 & 1222 & 1029 & 92.4 & 1.69 & 0.40 & 21 \\
\hline 15 & Sumska & 475 & 1305 & 993 & 93.6 & 1.73 & 0.41 & 20 \\
\hline 16 & Poltavska & 618 & 1703 & 961 & 97.5 & 1.85 & 0.44 & 19 \\
\hline 17 & Kharkivska & 1165 & 8183 & 1743 & 110.2 & 2.34 & 0.56 & 6 \\
\hline \multicolumn{9}{|c|}{ Southern RREM } \\
\hline 18 & Odeska & 1300 & 9089 & 2423 & 100.6 & 2.16 & 0.51 & 9 \\
\hline 19 & Mykolayivska & 115 & 1087 & 920 & 103.1 & 1.99 & 0.47 & 15 \\
\hline 20 & Khersonska & 139 & 896 & 776 & 76.6 & 1.23 & 0.29 & 23 \\
\hline 21 & AR Crimea & - & - & - & - & - & - & - \\
\hline 22 & SEVASTOPOL & - & - & - & - & - & - & - \\
\hline \multicolumn{9}{|c|}{ Eastern RREM } \\
\hline 23 & Dnipropretrovska & 750 & 3203 & 904 & 106.5 & 2.12 & 0.50 & 10 \\
\hline 24 & Zaporizka & 66 & 1086 & 621 & 86.6 & 1.51 & 0.36 & 22 \\
\hline 25 & Donetska & 82 & 319 & 136 & 67.1 & 0.94 & 0.22 & 24 \\
\hline 26 & Luhanska & 24 & 58 & 32 & 34.4 & 0.00 & 0.00 & 25 \\
\hline \multicolumn{9}{|c|}{ Capital RREM } \\
\hline 27 & KYIV & 5249 & 20265 & 4640 & 96.0 & 3.25 & 0.77 & 2 \\
\hline
\end{tabular}

The index " 0 " designates the lowest level of each indicator in the formula (16). For a more comfortable housing supply evaluation, we will perform the normalisation of the SU parameter by the ratio:

$I_{S U}=\left(S U-S U_{\text {min }}\right) /\left(S U_{\text {max }}-S U_{\text {min }}\right)$.

where $\mathrm{SU}_{\min }$ - the minimum value of the $\mathrm{SU}$ in all regions, SUmax - the maximum value of this indicator. The minimum value of the ISU housing index (penultimate column in Table 3) is 0 , the maximum value is 1 and it has a vivid economic interpretation: 0 - the minimum supply level, 1 - the level of the maximum supply. Using the supply index facilitates ranking the regions by this indicator (last column in Table 3). It is obvious that the highest housing supply is observed in Kyiv, Kyivska, Khmelnytska, Lvivska and Volynska regions. The lowest housing supply was registered in Donetska, Luhanska, Khersonska and Zaporizka regions.

Using the data in Table 3, the value of integral indicator of housing supply SU is calculated for the regions of Ukraine. The results of calculations are given in Table 9. The highest housing supply value is characteristic of the capital RREM. High housing supply is also available in central and western RREM, the lowest supply in the eastern RREM of Ukraine. 
Tab. 4 - Housing affordability in Ukraine regions according to their division into RREM, on January 1, 2017, (excluding the temporarily occupied territory of the Autonomous Rep. of Crimea, the city of Sevastopol and parts of the zone of anti-terrorist operation in Donetska, Luhanska regions). Source: Ministry of Justice of Ukraine. (2019), State Statistics Service of Ukraine (2019).

\begin{tabular}{|c|c|c|c|c|c|}
\hline \multicolumn{2}{|c|}{ Region } & $\begin{array}{l}\text { Housing price, } \\
\$ / \mathrm{m}^{2}\end{array}$ & $\begin{array}{l}\text { Housing afford- } \\
\text { ability indicator }\end{array}$ & $\begin{array}{l}\text { Housing affordabil- } \\
\text { ity index }\end{array}$ & $\begin{array}{l}\text { Region's } \\
\text { rating }\end{array}$ \\
\hline \multicolumn{6}{|c|}{ Western RREM } \\
\hline 1 & Volynska & 575 & 0.23 & 0.81 & 14 \\
\hline 2 & Rivnenska & 555 & 0.36 & 0.84 & 9.5 \\
\hline 3 & Lvivska & 898 & -1.78 & 0.33 & 24 \\
\hline 4 & Ternopilska & 450 & 1.01 & 1.00 & 2 \\
\hline 5 & Khmelnytska & 460 & 0.95 & 0.99 & 4 \\
\hline 6 & Zakarpatska & 629 & -0.10 & 0.73 & 17 \\
\hline 7 & Ivano-Frankivska & 574 & 0.24 & 0.82 & 13 \\
\hline 8 & Chernihivska & 485 & 0.79 & 0.95 & 6 \\
\hline \multicolumn{6}{|c|}{ Central RREM } \\
\hline 9 & Kyivska & 822 & -1.31 & 0.45 & 23 \\
\hline 10 & Zhytomyrska & 566 & 0.29 & 0.83 & 11 \\
\hline 11 & Vinnytska & 630 & -0.11 & 0.73 & 18 \\
\hline 12 & Cherkaska & 514 & 0.61 & 0.90 & 8 \\
\hline 13 & Kirovohradska & 473 & 0.87 & 0.97 & 5 \\
\hline \multicolumn{6}{|c|}{ Northern RREM } \\
\hline 14 & Chernivetska & 669 & -0.35 & 0.67 & 20 \\
\hline 15 & Sumska & 487 & 0.78 & 0.94 & 7 \\
\hline 16 & Poltavska & 573 & 0.24 & 0.82 & 12 \\
\hline 17 & Kharkivska & 695 & -0.52 & 0.64 & 21 \\
\hline \multicolumn{6}{|c|}{ Southern RREM } \\
\hline 18 & Odeska & 819 & -1.29 & 0.45 & 22 \\
\hline 19 & Mykolayivska & 555 & 0.36 & 0.84 & 9.5 \\
\hline 20 & Khersonska & 594 & 0.11 & 0.79 & 15 \\
\hline 21 & AR Crimea & - & - & - & - \\
\hline 22 & SEVASTOPOL & - & - & - & - \\
\hline \multicolumn{6}{|c|}{ Eastern RREM } \\
\hline 23 & Dnipropetrovska & 662 & -0.31 & 0.68 & 19 \\
\hline 24 & Zaporizka & 599 & 0.08 & 0.78 & 16 \\
\hline 25 & Donetska & 450 & 1.01 & 1.00 & 2 \\
\hline 26 & Luhanska & 450 & 1.01 & 1.00 & 2 \\
\hline \multicolumn{6}{|c|}{ Capital RREM } \\
\hline 27 & KYIV & 1122 & -3.18 & 0.00 & 25 \\
\hline
\end{tabular}




\section{Analysis of "housing affordability" component}

Proceeding with the analysis of the components of the regional competitiveness index of RREM "housing affordability" presupposes that this component depends on a single indicator - "housing price" (Table 4). After performing the standardisation procedure for the relation:

$A_{i}=\left(H P_{a}-H P_{i}\right) / S_{i}$

we get the value of the housing affordability index $\mathrm{Ai}$ (the fourth column of Table 9). Here $\mathrm{HP}_{\mathrm{i}}$ - the price of housing in the $\mathrm{i}$-th area, $\mathrm{HP}_{\mathrm{a}}$ - the average value of housing, si - the standard deviation of the "housing price" indicator. For a more comfortable estimation of housing affordability, we will perform the valuation of $\mathrm{A}$ indicator:

$I_{A}=\left(A-A_{\min }\right) /\left(A_{\max }-A_{\min }\right)$.

Tab. 5 - Purchasing power of citizens in Ukraine regions according to their division into RREM, on January 1, 2017, (excluding the temporarily occupied territory of the Autonomous Republic of Crimea, the city of Sevastopol and parts of the zone of the anti-terrorist operation in Donetska and Luhanska regions). Source: Ministry of Justice of Ukraine. (2019), State Statistics Service of Ukraine (2019).

\begin{tabular}{|c|c|c|c|c|c|c|c|c|}
\hline \multicolumn{2}{|c|}{ Region } & $\begin{array}{l}\text { GRP per } \\
\text { person, } \\
\text { '000 } \\
\text { UAH }\end{array}$ & $\begin{array}{l}\text { Income } \\
\text { per cap- } \\
\text { ita, '000 } \\
\text { UAH }\end{array}$ & $\begin{array}{l}\text { Average } \\
\text { salary, } \\
\text { UAH }\end{array}$ & $\begin{array}{l}\text { Unem- } \\
\text { ployment } \\
\text { rate, } \%\end{array}$ & $\begin{array}{l}\text { Pur- } \\
\text { chasing } \\
\text { capacity }\end{array}$ & $\begin{array}{l}\text { Pur- } \\
\text { chasing } \\
\text { capacity } \\
\text { index }\end{array}$ & $\begin{array}{l}\text { Region's } \\
\text { rating }\end{array}$ \\
\hline \multicolumn{9}{|c|}{ Western RREM } \\
\hline 1 & Volynska & 30387 & 28312 & 7249 & 11.5 & 1.20 & 0.19 & 22 \\
\hline 2 & Rivnenska & 30350 & 29757 & 7676 & 10.6 & 1.41 & 0.24 & 17 \\
\hline 3 & Lvivska & 37338 & 33673 & 7879 & 7.7 & 2.04 & 0.37 & 6 \\
\hline 4 & Ternopilska & 24963 & 26884 & 6828 & 11.5 & 1.13 & 0.18 & 24 \\
\hline 5 & Khmelnytska & 31660 & 32650 & 7559 & 9.4 & 1.67 & 0.29 & 11 \\
\hline 6 & Zakarpatska & 22989 & 25045 & 8127 & 10 & 1.47 & 0.25 & 16 \\
\hline 7 & Ivano-Frankivska & 33170 & 29975 & 6935 & 8.8 & 1.72 & 0.30 & 10 \\
\hline 8 & Chernivetska & 20338 & 26838 & 7265 & 8.7 & 1.67 & 0.29 & 13 \\
\hline \multicolumn{9}{|c|}{ Central RREM } \\
\hline 9 & Kyivska & 60109 & 39178 & 8719 & 6.8 & 2.48 & 0.46 & 2 \\
\hline 10 & Zhytomyrska & 30698 & 31441 & 7207 & 11.2 & 1.31 & 0.21 & 19 \\
\hline 11 & Vinnytska & 37270 & 33849 & 7613 & 9.7 & 1.67 & 0.29 & 12 \\
\hline 12 & Cherkaska & 40759 & 30609 & 7267 & 10.4 & 1.49 & 0.25 & 15 \\
\hline 13 & Kirovohradska & 39536 & 30980 & 6798 & 12.4 & 1.16 & 0.18 & 23 \\
\hline \multicolumn{9}{|c|}{ Northern RREM } \\
\hline 14 & Chernihivska & 35196 & 31707 & 6656 & 11.3 & 1.31 & 0.21 & 18 \\
\hline 15 & Sumska & 37170 & 33944 & 7359 & 9.3 & 1.72 & 0.30 & 9 \\
\hline 16 & Poltavska & 66390 & 36393 & 7839 & 12.6 & 1.59 & 0.27 & 14 \\
\hline 17 & Kharkivska & 45816 & 36588 & 7447 & 6.4 & 2.34 & 0.43 & 4 \\
\hline
\end{tabular}




\begin{tabular}{|c|c|c|c|c|c|c|c|c|}
\hline \multicolumn{9}{|c|}{ Southern RREM } \\
\hline 18 & Odeska & 41682 & 37732 & 8297 & 6.8 & 2.31 & 0.42 & 5 \\
\hline 19 & Mykolayivska & 41501 & 33187 & 8828 & 9.7 & 1.81 & 0.32 & 8 \\
\hline 20 & Khersonska & 30246 & 31243 & 7206 & 11.2 & 1.30 & 0.21 & 20 \\
\hline 21 & AR Crimea & - & - & - & - & - & - & - \\
\hline 22 & SEVASTOPOL & - & - & - & - & - & - & - \\
\hline \multicolumn{9}{|c|}{ Eastern RREM } \\
\hline 23 & Dnipropetrovska & 65897 & 43458 & 8247 & 7.9 & 2.37 & 0.43 & 3 \\
\hline 24 & Zaporizka & 50609 & 42118 & 8305 & 10 & 1.92 & 0.34 & 7 \\
\hline 25 & Donetska & 26864 & 19434 & 9886 & 14.1 & 1.24 & 0.20 & 21 \\
\hline 26 & Luhanska & 10778 & 11920 & 7484 & 16 & 0.28 & 0.00 & 25 \\
\hline \multicolumn{9}{|c|}{ Capital RREM } \\
\hline 27 & KYIV & 155904 & 91357 & 14035 & 6.7 & 5.08 & 1.00 & 1 \\
\hline
\end{tabular}

In this formula, $A_{\min }$ is the minimum value of $A$ indicator in all regions, $A_{\max }$ is the maximum value of this indicator. The value of housing affordability index $I_{A}$ varies from 0 to 1 ( 0 is the minimum affordability level, 1 is the level of maximum affordability).

Using the proposed methodology, the value of integral indicator of housing affordability for the regions of Ukraine is calculated. In the analysis of Table 4, 9 illustrates that housing is the most affordable in the eastern and northern RREM of Ukraine, while the most expensive housing is in Kyiv (capital RREM).

\section{Analysis of the integral component of the "purchasing capacity of citizens" PCC}

The purchasing power is determined by such factors as the gross regional product per capita (GRP), the average salary per region (AS), the income per capita (CI) and the unemployment rate (UR). All these indicators are given in Table 5;

Tab. 6 - The living comfort level in Ukraine regions by their division into RREM, on January 1, 2017, (excluding the temporarily occupied territory of the Autonomous Republic of Crimea, the city of Sevastopol and parts of the zone of anti-terrorist operation in Donetska and Luhanska regions). Source: Ministry of Justice of Ukraine. (2019), State Statistics Service of Ukraine (2019).

\begin{tabular}{|c|c|c|c|c|c|c|c|c|}
\hline \multicolumn{2}{|c|}{ Region } & 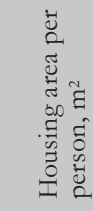 & 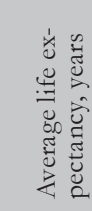 & 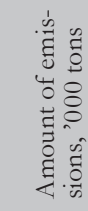 & 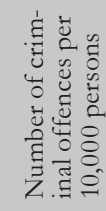 & 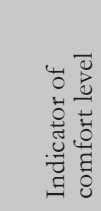 & 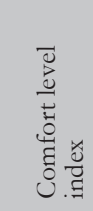 & 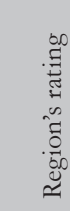 \\
\hline \multicolumn{9}{|c|}{ Western RREM } \\
\hline 1 & Volynska & 22.5 & 71.5 & 0.14 & 9 & 2.74 & 0.85 & 6 \\
\hline 2 & Rivnenska & 22 & 71.35 & 0.29 & 9 & 2.69 & 0.84 & 8 \\
\hline 3 & Lvivska & 22.8 & 73.3 & 1.08 & 13 & 2.61 & 0.81 & 10 \\
\hline 4 & Ternopilska & 25.5 & 73.35 & 0.32 & 9 & 3.03 & 0.94 & 2 \\
\hline
\end{tabular}




\begin{tabular}{|c|c|c|c|c|c|c|c|c|}
\hline 5 & Khmelnytska & 26.3 & 71.8 & 0.45 & 9 & 2.81 & 0.88 & 5 \\
\hline 6 & Zakarpatska & 24.2 & 70.7 & 0.15 & 10 & 2.63 & 0.82 & 9 \\
\hline 7 & Ivano-Frankivska & 25.7 & 73.2 & 4.88 & 8 & 2.49 & 0.78 & 15 \\
\hline 8 & Chernivetska & 24.4 & 73 & 0.17 & 10 & 2.90 & 0.91 & 4 \\
\hline \multicolumn{9}{|c|}{ Central RREM } \\
\hline 9 & Kyivska & 35.1 & 70 & 0.75 & 12 & 3.21 & 1.00 & 1 \\
\hline 10 & Zhytomyrska & 27 & 69.6 & 0.23 & 12 & 2.57 & 0.80 & 11 \\
\hline 11 & Vinnytska & 29.3 & 72 & 2.24 & 12 & 2.55 & 0.79 & 12 \\
\hline 12 & Cherkaska & 27.7 & 72 & 1.12 & 14 & 2.51 & 0.78 & 13 \\
\hline 13 & Kirovohradska & 25.7 & 70.3 & 0.37 & 17 & 2.25 & 0.70 & 20 \\
\hline \multicolumn{9}{|c|}{ Northern RREM } \\
\hline 14 & Chernihivska & 28.8 & 70.2 & 0.92 & 15 & 2.42 & 0.75 & 16 \\
\hline 15 & Sumska & 25.4 & 71.2 & 0.42 & 21 & 2.16 & 0.67 & 23 \\
\hline 16 & Poltavska & 25.4 & 71.2 & 0.58 & 15 & 2.35 & 0.73 & 18 \\
\hline 17 & Kharkivska & 24.1 & 71.15 & 0.42 & 14 & 2.38 & 0.74 & 17 \\
\hline \multicolumn{9}{|c|}{ Southern RREM } \\
\hline 18 & Odeska & 22.5 & 70.4 & 0.26 & 8 & 2.70 & 0.84 & 7 \\
\hline 19 & Mykolayivska & 22.3 & 70.3 & 0.33 & 11 & 2.49 & 0.78 & 14 \\
\hline 20 & Khersonska & 24 & 69.95 & 0.27 & 16 & 2.24 & 0.70 & 21 \\
\hline 21 & AR Crimea & - & - & - & - & - & - & -- \\
\hline 22 & SEVASTOPOL & - & - & - & - & - & - & - \\
\hline \multicolumn{9}{|c|}{ Eastern RREEM } \\
\hline 23 & Dnipropetrovska & 24.3 & 69.9 & 3.36 & 8 & 2.20 & 0.69 & 22 \\
\hline 24 & Zaporizka & 23.4 & 71.1 & 2.17 & 10 & 2.28 & 0.71 & 19 \\
\hline 25 & Donetska & 22 & 69.6 & 7.94 & 26 & 0.00 & 0.00 & 25 \\
\hline 26 & Luhanska & 22 & 69.6 & 4.83 & 25 & 0.80 & 0.25 & 24 \\
\hline \multicolumn{9}{|c|}{ Capital RREM } \\
\hline 27 & KYIV & 22.6 & 74 & 0.06 & 12 & 2.98 & 0.93 & 3 \\
\hline
\end{tabular}

the first three are stimulants, the fourth is a destimulant. We perform standardisation of indicators by the proposed method. After that, the integral purchasing capacity indicator of the PCC is calculated by the ratio:

$$
P C C_{i}=\sqrt{\left.\left(G R P_{i}-G R P_{0}\right)^{2}+\left(A S_{i}-A S_{0}\right)^{2}+\left(C I_{i}-C I_{0}\right)^{2}+\left(U R_{i}-U R_{0}\right)^{2}\right] / 4} \cdot
$$

The index " 0 " designates the lowest level of all the indicators in the formula (20). For a more convenient assessment of the purchasing capacity of citizens, the normalisation of the PCC will be performed by the ratio

$I_{p c c}=\left(P C C-P C C_{\text {min }}\right) /\left(P C C_{\max }-P C C_{\min }\right)$.

In this table, $\mathrm{PCC}_{\min }$ is the minimum value of purchasing capacity among all areas, $\mathrm{PCC}_{\max }$ is the maximum value of this indicator. 
The minimum value of the purchasing capacity index of IPCC (penultimate column of Table 5) is 0 (the minimum purchasing capacity level), the maximum value is equal to 1 (the maximum purchasing capacity level). Using the purchasing capacity index, the RREM rating is calculated for this indicator (last column in Table 5). The purchasing capacity of citizens residing in the city of Kyiv is shown the highest in the table. A sufficient purchasing capacity is for the citizens living in Kyiv, Kharkivska, Dnipropetrovska and Odeska regions. The lowest purchasing capacity is typical of Volynska, Donetska, Zhytomyrska, Kirovohradska, Luhanska, Ternopilska, Khersonska and Chernihivska regions. The integral indicator value of citizens' purchasing capacity PCC for the regions of Ukraine was calculated using the proposed methodology. As shown in Figure 6, the largest purchasing capacity of citizens is in the capital RREM (Kyiv). This indicator is much (8-10 times) higher than the purchasing capacity of citizens in other regions. The lowest purchasing capacity of citizens was observed in the western and central RREM.

The analysis of integral component "level of comfort" of the region is determined by factors such as the average area of housing stock per person (HA), the average life expectancy (LE), the amount of harmful emissions into the atmosphere (EA), and the number of criminal offences (CO) (Table 6). The first two factors are stimulants, the last two destimulants. We therefore performed the standardisation of indicators and calculated the integral indicator of comfort level CL by the ratio

$C L_{i}=\sqrt{\left.\left(H A_{i}-H A_{0}\right)^{2}+\left(L E_{i}-L E_{0}\right)^{2}+\left(E A_{i}-E A_{0}\right)^{2}+\left(C O_{i}-C O_{0}\right)^{2}\right] / 4} \cdot$

Index " 0 " indicates the lowest level of each of the indicators in formula (22). To conveniently assess the region's level of comfort, we will perform the normalization of ind. CL by the ratio:

$I_{C L}=\left(C L-C L_{\text {min }}\right) /\left(C L_{\text {max }}-C L_{\text {min }}\right)$.

Thus, $\mathrm{CL}_{\min }$ is the minimum level of comfort among all areas, $\mathrm{CL}_{\max }$ is the maximum value of this indicator.

The minimum value of the comfort level index of the ICL (penultimate column of Table 6) is characteristic of the Donetska and Luganska regions (areas close to the war zone). A low level of living comfort is characteristic of the Dnipropetrovska, Zaporizka, Sumska, Chernihivska, Kharkivska, Poltavska, Kirovogradska and Khersonska regions. A high level of comfort is in the Kyiv and Kyivska region, as well as in the Ternopilska, Khmelnytska, and Chernivetska regions.

The integral indicator of comfort level CL for Ukraine's RREM was calculated on the basis of the proposed methodology. The highest level of living comfort is characteristic of the capital area, whereas the lowest was observed in the eastern RREM (Table 9), where it is 7 times lower than the indicator for Kyiv (Capital RREM).

\section{Analysis of the integral component "geographic and cultural advantages of the region"}

The geographical advantages and disadvantages of the RREM are determined by its proximity to the war zone, proximity to the sea and the EU border, etc. Cultural benefits are related to the presence of cultural and historical monuments as well as tourist attractions in the region. We determined the level of geographical and cultural benefits by an expert survey using a 4-point scale. 
In this case, the score of 4 testified to the maximum benefits of the region, whereas the score of 0 indicated that there was no advantage, or that there were significant shortcomings (Tab. 7).

We performed standardization of the indicators and calculated the integral index of cultural and geographical advantages GCA by the ratio:

$$
G C A_{i}=\sqrt{\left[\left(G A_{i}-G A_{0}\right)^{2}+\left(C A_{i}-C A_{0}\right)^{2}\right] / 2} .
$$

Index "0" designates the lowest level of each indicator.

For a more user-friendly assessment of the level of geographical and cultural advantages, the normalisation of GCA indicator will be performed by the ratio:

$I_{G C A}=\left(G C A-G C A_{\text {min }}\right) /\left(G C A_{\max }-G C A_{\text {min }}\right)$.

Here $\mathrm{GCA}_{\min }$ indicates the minimum value of the level of geographical and cultural benefits in all regions, and max indicates the maximum value of this indicator. The minimum index value of the level of geographical and cultural benefits (advantages) GCA (penultimate column of Table 7) is characteristic of the Donetska and Luhanska regions. A low level of this indicator is also observed in the Dnipropetrovska, Kharkivska, and Khersonska regions.

Tab. 7 - Cultural and geographical advantages of Ukraine regions in terms of their division into RREM, on January 1, 2017, (excluding the temporarily occupied territory of the Autonomous Republic of Crimea, the city of Sevastopol and parts of the zone of the anti-terrorist operation in Donetska and Luhanska regions). Source: own research

\begin{tabular}{|c|c|c|c|c|c|c|}
\hline \multicolumn{2}{|c|}{ Region } & $\begin{array}{l}\text { Geographical } \\
\text { advantages }\end{array}$ & $\begin{array}{l}\text { Cultural } \\
\text { advantages }\end{array}$ & $\begin{array}{l}\text { Geographical } \\
\text { advantages } \\
\text { indicator }\end{array}$ & $\begin{array}{l}\text { Advantages } \\
\text { level index }\end{array}$ & $\begin{array}{l}\text { Region's } \\
\text { rating }\end{array}$ \\
\hline \multicolumn{7}{|c|}{ Western RREM } \\
\hline 1 & Volynska & 4 & 0 & 2.368 & 0.809 & 7 \\
\hline 2 & Rivnenska & 3 & 0 & 1.776 & 0.607 & 13 \\
\hline 3 & \begin{tabular}{|l|} 
Lvivska \\
\end{tabular} & 4 & 2 & 2.926 & 1.000 & 1.5 \\
\hline 4 & Ternopilska & 3 & 0 & 1.776 & 0.607 & 13 \\
\hline 5 & Khmelnytska & 3 & 0 & 1.776 & 0.607 & 13 \\
\hline 6 & Zakarpatska & 4 & 2 & 2.926 & 1.000 & 1.5 \\
\hline 7 & $\begin{array}{l}\text { Ivano-Frankivs- } \\
\mathrm{ka}\end{array}$ & 3 & 2 & 2.472 & 0.845 & 5 \\
\hline 8 & Chernivetska & 4 & 1 & 2.519 & 0.861 & 3 \\
\hline \multicolumn{7}{|c|}{ Central RREM } \\
\hline 9 & Kyivska & 3 & 0 & 1.776 & 0.607 & 13 \\
\hline 10 & Zhytomyrska & 3 & 0 & 1.776 & 0.607 & 13 \\
\hline 11 & Vinnytska & 3 & 0 & 1.776 & 0.607 & 13 \\
\hline 12 & Cherkaska & 3 & 0 & 1.776 & 0.607 & 13 \\
\hline 13 & Kirovohradska & 3 & 0 & 1.776 & 0.607 & 13 \\
\hline
\end{tabular}




\begin{tabular}{|c|c|c|c|c|c|c|}
\hline \multicolumn{7}{|c|}{ Northern RREM } \\
\hline 14 & Chernihivska & 2 & 0 & 1.184 & 0.405 & 18.5 \\
\hline 15 & Sumska & 2 & 0 & 1.184 & 0.405 & 18.5 \\
\hline 16 & Poltavska & 3 & 1 & 1.973 & 0.674 & 8 \\
\hline 17 & Kharkivska & 1 & 0 & 0.592 & 0.202 & 22 \\
\hline \multicolumn{7}{|c|}{ Southern RREM } \\
\hline 18 & Odeska & 3 & 2 & 2.472 & 0.845 & 5 \\
\hline 19 & Mykolayivska & 3 & 0 & 1.776 & 0.607 & 13 \\
\hline 20 & Khersonska & 1 & 0 & 0.592 & 0.202 & 22 \\
\hline 21 & AR Crimea & - & - & - & - & - \\
\hline 22 & SEVASTOPOL & - & - & - & - & - \\
\hline \multicolumn{7}{|c|}{ Eastern RREM } \\
\hline 23 & $\begin{array}{l}\text { Dnipropetro- } \\
\text { vska }\end{array}$ & 1 & 0 & 0.592 & 0.202 & 22 \\
\hline 24 & Zaporizka & 1 & 1 & 1.044 & 0.357 & 20 \\
\hline 25 & Donetska & 0 & 0 & 0.000 & 0.000 & 24.5 \\
\hline 26 & Luhanska & 0 & 0 & 0.000 & 0.000 & 24.5 \\
\hline \multicolumn{7}{|c|}{ Capital RREM } \\
\hline 27 & KYIV & 3 & 2 & 2.472 & 0.845 & 5 \\
\hline
\end{tabular}

The value of the integral indicator of the geographical and cultural advantages GCA was calculated for Ukraine's RREM. The highest level of this indicator was shown for the capital and western RREM, whereas the lowest level of geographical and cultural benefits can be observed in the eastern RREM (Table 9).

\section{The construction of integral indicator of real estate market competitiveness in the region}

We combined the results of retrieved calculations into Table 8. Taking into account the fact that the minimum value of each integral index is zero, the integral index of real estate market competitiveness for Ukraine regions will be calculated by the formula:

$I_{C L}=\sqrt{\left(I_{D E}^{2}+I_{S U}^{2}+I_{A}^{2}+I_{P C C}^{2}+I_{C L}^{2}+I_{G C A^{2}}\right)^{2} / 6}$

The results of calculations are given in the penultimate column of Table 8. The highest integral index of real estate market competitiveness was found for the Kyiv and Kyivska region. A high value of the index of competitiveness was found for the Volynska, Zakarpatska, Ivano-Frankivska, Lvivska, Ternopilska, Khmelnytska and Chernivetska regions. 
Tab. 8 - Integral indices of real estate market competitiveness for Ukraine oblasts by their division into RREM, on January 1, 2017, (excluding the temporarily occupied territory of the Autonomous Republic of Crimea, the city of Sevastopol and parts of the zone of anti-terrorist operation in Donetska and Luhanska oblasts). Source: own research

\begin{tabular}{|c|c|c|c|c|c|c|c|c|c|}
\hline \multicolumn{2}{|c|}{ Region } & 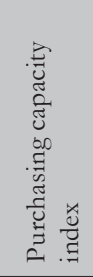 & 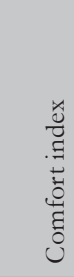 & 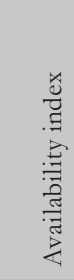 & 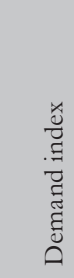 & 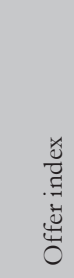 & 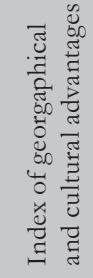 & 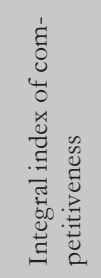 & 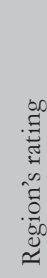 \\
\hline \multicolumn{10}{|c|}{ Western RREM } \\
\hline 1 & Volynska & 0.19 & 0.85 & 0.81 & 0.22 & 0.61 & 0.81 & 0.65 & 5 \\
\hline 2 & Rivnenska & 0.24 & 0.84 & 0.84 & 0.24 & 0.53 & 0.61 & 0.60 & 11 \\
\hline 3 & Lvivska & 0.37 & 0.81 & 0.33 & 0.34 & 0.63 & 1.00 & 0.64 & 7 \\
\hline 4 & Ternopilska & 0.18 & 0.94 & 1.00 & 0.21 & 0.49 & 0.61 & 0.66 & 4 \\
\hline 5 & Khmelnytska & 0.29 & 0.88 & 0.99 & 0.31 & 0.64 & 0.61 & 0.67 & 3 \\
\hline 6 & Zakarpatska & 0.25 & 0.82 & 0.73 & 0.12 & 0.46 & 1.00 & 0.65 & 6 \\
\hline 7 & Ivano-Frankivska & 0.30 & 0.78 & 0.82 & 0.18 & 0.50 & 0.84 & 0.63 & 8 \\
\hline 8 & Chernivetska & 0.29 & 0.91 & 0.67 & 0.22 & 0.45 & 0.86 & 0.63 & 9 \\
\hline \multicolumn{10}{|c|}{ Central RREM } \\
\hline 9 & Kyivska & 0.46 & 1.00 & 0.45 & 1.00 & 1.00 & 0.61 & 0.79 & 2 \\
\hline 10 & Zhytomyrska & 0.21 & 0.80 & 0.83 & 0.26 & 0.51 & 0.61 & 0.59 & 15 \\
\hline 11 & Vinnyska & 0.29 & 0.79 & 0.73 & 0.23 & 0.49 & 0.61 & 0.56 & 17 \\
\hline 12 & Cherkaska & 0.25 & 0.78 & 0.90 & 0.26 & 0.49 & 0.61 & 0.60 & 12 \\
\hline 13 & Kirovohradska & 0.18 & 0.70 & 0.97 & 0.24 & 0.46 & 0.61 & 0.59 & 13 \\
\hline \multicolumn{10}{|c|}{ Northern RREM } \\
\hline 14 & Chernihivska & 0.21 & 0.75 & 0.95 & 0.27 & 0.40 & 0.40 & 0.56 & 18 \\
\hline 15 & Sumska & 0.30 & 0.67 & 0.94 & 0.21 & 0.41 & 0.40 & 0.55 & 19 \\
\hline 16 & Poltavska & 0.27 & 0.73 & 0.82 & 0.29 & 0.44 & 0.67 & 0.58 & 16 \\
\hline 17 & Kharkivska & 0.43 & 0.74 & 0.64 & 0.45 & 0.56 & 0.20 & 0.53 & 20 \\
\hline \multicolumn{10}{|c|}{ Southern RREM } \\
\hline 18 & Odeska & 0.42 & 0.84 & 0.45 & 0.43 & 0.51 & 0.84 & 0.61 & 10 \\
\hline 19 & Mykolayivska & 0.32 & 0.78 & 0.84 & 0.28 & 0.47 & 0.61 & 0.59 & 14 \\
\hline 20 & Khersonska & 0.21 & 0.70 & 0.79 & 0.27 & 0.29 & 0.20 & 0.47 & 23 \\
\hline 21 & AR Crimea & - & - & - & - & - & - & - & - \\
\hline 22 & SEVASTOPOL & - & - & - & - & - & - & - & - \\
\hline \multicolumn{10}{|c|}{ Eastern RREM } \\
\hline 23 & Dnipropetrovska & 0.43 & 0.69 & 0.68 & 0.37 & 0.50 & 0.20 & 0.51 & 21 \\
\hline 24 & Zaporizka & 0.34 & 0.71 & 0.78 & 0.27 & 0.36 & 0.36 & 0.51 & 22 \\
\hline 25 & Donetska & 0.20 & 0.00 & 1.00 & 0.06 & 0.22 & 0.00 & 0.43 & 24 \\
\hline
\end{tabular}




\begin{tabular}{|l|l|l|l|l|l|l|l|l|l|}
\hline 26 & Luhanska & 0.00 & 0.25 & 1.00 & 0.00 & 0.00 & 0.00 & 0.42 & 25 \\
\hline Capital RREM \\
\hline 27 & KYIV & 1.00 & 0.93 & 0.00 & 0.80 & 0.77 & 0.84 & 0.80 & 1 \\
\hline
\end{tabular}

The lowest index value of real estate market competitiveness is characteristic of the Donetska and Luganska regions, with a low index value also observed for the Dnipropetrovska, Zaporizka and Khersonska regions.

The integral indicator value of real estate market competitiveness for the regions of Ukraine was calculated according to the formula

$R C_{i}=\sqrt{\left.\left(D E_{i}-D E_{0}\right)^{2}+\left(S U_{i}-S U_{0}\right)^{2}+\left(A_{i}-A_{0}\right)^{2}+\left(P C C_{i}-P C C_{0}\right)^{2}+\left(C L_{i}-C L_{0}\right)^{2}+\left(G C A_{i}-G C A_{0}\right)^{2}\right] / 6}$

in which $i$ means the number of the region, and the index " 0 " designates the lowest level of each of indicator included in formula (27) among all six regions of Ukraine. As shown in Table 9, the capital (Kyiv) has the highest integral indicator value of real estate market competitiveness. The southern region has the lowest competitiveness level.

Tab. 9 - Integral competitiveness components of Ukraine RREM. Source: own research

\begin{tabular}{|l|l|l|l|l|l|l|l|}
\hline & $\begin{array}{l}\text { Pur- } \\
\text { chasing } \\
\text { capacity } \\
\text { indicator }\end{array}$ & $\begin{array}{l}\text { Comfort } \\
\text { indicator }\end{array}$ & $\begin{array}{l}\text { Afford- } \\
\text { ability } \\
\text { indicator }\end{array}$ & $\begin{array}{l}\text { Demand } \\
\text { indicator }\end{array}$ & $\begin{array}{l}\text { Supply } \\
\text { indicator }\end{array}$ & $\begin{array}{l}\text { Geo- } \\
\text { graphical } \\
\text { advantages } \\
\text { indicator }\end{array}$ & $\begin{array}{l}\text { Integral } \\
\text { indicator } \\
\text { of com- } \\
\text { petitive- } \\
\text { ness }\end{array}$ \\
\hline Western & 0.263 & 1.373 & 3.348 & 0.263 & 1.053 & 2.001 & 1.637 \\
\hline Central & 0.381 & 1.489 & 3.335 & 0.508 & 1.595 & 1.357 & 1.642 \\
\hline Northern & 0.494 & 1.101 & 3.543 & 0.451 & 0.562 & 0.941 & 1.526 \\
\hline Southern & 0.541 & 1.051 & 2.993 & 0.463 & 0.534 & 1.460 & 1.359 \\
\hline Eastern & 0.541 & 0.235 & 3.671 & 0.374 & 0.000 & 0.430 & 1.504 \\
\hline Capital & 4.046 & 1.781 & 0.000 & 1.000 & 2.538 & 2.190 & 2.113 \\
\hline
\end{tabular}

Thus, our overview of real estate market competitiveness within regions of Ukraine was characterised based on our developed methodology for assessing the integral competitiveness indicator of each market. This technique has allowed us to estimate integral indicator of each region's competitiveness, as well as of individual integral components, the results of which are illustrated in Table 9.

\section{CONCLUSION}

A number of methodological approaches were employed in our study for the assessment of the competitiveness capacity of regional residential real estate markets and among their participants. Our methodology involved constructing integral indices of the construction market, an integral component analysis of the following factors: " housing demand," " housing supply," housing affordability," "purchasing capacity of citizens," "comfort level," along with the "geographical and cultural advantages of the region." On the basis of our research results, the integral indicator 
of competitive capacity of the residential real estate market within each region was constructed. With the results of the combination of statistical indicators and integral components used, it is possible to estimate that the capital region has an overwhelming lead in almost all indicators, this in addition to the factor of housing accessibility, since the price of housing in Kiev is twice as high as in other regions of Ukraine. The unique advantage of the eastern region is its low housing prices, but this advantage cannot compensate for the disadvantages associated with its proximity to the zone of military conflict. The disadvantage of the western and central regions is the low purchasing capacity of citizens, whereas the weakness of the southern region is in its insufficient supply of new housing. The northern region was not found to be very attractive in terms of geographical and cultural advantages.

\section{References}

1. Bazylyuk, YA. B. (2002). Competitiveness of the national economy: the essence and conditions of the provision. Kyiv: NIS.

2. Fatkhutdinov, R. A. (2002). Competitiveness: economics, strategy, management. Moscow: InfraM.

3. Filipenko, A. S. (2010). Economic Globalization: Origins and Results. Moscow: Economy.

4. Garbar, Zh. V. (2019). Peculiarities of functioning of the real estate market at the regional level. Scientific conferences Retrieved August 1, 2019 from http://intkonf.org/garbar-zhvbogatska- yua-osoblivosti-funktsionuvannya-rinku-neruhomosti-na-regionalnomu-rivni.

5. Ginevicius, R. (2019). Quantitative Assessment of the Compatibility of the Development of Socioeconomic Systems. Journal of Competitiveness, 11 (2), 36-50. https://doi.org/10.7441/ joc. 2019.02 .03

6. Keynes, J. (1999). The general theory of employment, interest and money. Moscow: Gelios ARV.

7. Mann, D., \& Wright, D. (2010). Innovations and the limits of antitrust policy. Journal of Competition Law of Economics, 6 (1), 153-202.

8. Mann, R. V. (2007). Features of the diagnosis of the state and prospects for the development of the real estate market. Economy \& the state, 9 (1), 15-17.

9. Marx, K. (1867). Capital. A Critique of Political Economy. Moscow: Progress Publishers.

10. Ministry of Justice of Ukraine. (2019). Official site of the Ministry of Justice of Ukraine. Retrieved August 1, 2019 from https://minjust.gov.ua.

11. State Statistics Service of Ukraine. (2019). Official site State Statistics Service of Ukraine Retrieved August 1, 2019 from http://www.ukrstat.gov.ua

12. Pavlov, K. V. (2016). Features of Competitive Relations in Regional Real Estate Markets. Scientific Bulletin of Uzhogorod University. Series "Economics", 1 (2), 35-38.

13. Pavlov, K. (2018). Methodological Approaches to Determining the Monopolisation Level of Primary Residential Real Estate Regional Markets in Ukraine. Scientific journal "Economics, Entrepreneurship, Management”, 5 (3), 67-72. https://doi.org/10.23939/eem2018.01.063.

14. Piotrowska, M. (2019). Facets of Competitiveness in Improving the Professional Skills. Journal of Competitiveness, 11 (2), 95-112. https://doi.org/10.7441/joc.2019.02.07 
15. Plyuta, V. (1980). Comparative multivariate analysis in economic research: Taxonomy and factor analysis methods. M.: Statistika.

16. Porter, M. (2005). Competition. (O.L. Pelyavsky, A.P. Urikhanyan, \& E.L. Usenko. Trans.). Moscow: Williams.

17. Pozniak, S. V. (2015) Providing competitive advantage of domestic enterprises to international markets. Electronic Journal "Effective Economy", 11. Retrieved August 1, 2019 from http://www.economy.nayka.com.ua/?op $=1 \& z=4615$

18. Samuelson, P., \& William, D. (2010). Economics, 19th Ed. Nordhaus: McGraw Hill.

19. Strishenets, O. (2018). Social-economic estimation of competitive positions formation of Ukrainian regional residential real estate markets. Riga, Latvia: Baltija Publishing.

20. Valitov, S. S. (2006). Competitive Law of Ukraine: Teaching manual. Kyiv: Yurinkom Inter.

21. Zotov, I. V. (2008). The art of real estate operations. Kharkov: RIP Original.

\section{Contact information}

Associate Professor Kostiantyn Pavlov, Doctor of Economics

Lesya Ukrainka Eastern European National University

Faculty of Economics and Management

Department of Analytical Economics and Nature Management

Ukeraine

E-mail:pavlovkv@icloud.com

ORCID: 0000-0003-2583-9593

Professor Olena Pavlova (Strishenets), Doctor of Economics

Lesya Ukrainka Eastern European National University

Faculty of Economics and Management

Department of Analytical Economics and Nature Management

Ukraine

E-mail:pavlova.olena@eenu.edu.ua

ORCID: 0000-0002-8696-5641

Associate Professor Volodymyr Kupchak, Doctor of Economics

Lesya Ukrainka Eastern European National University

Faculty of Economics and Management

Department of Analytical Economics and Nature Management

Ukraine

E-mail:kupchak@me.com 